\title{
LICITAÇÕES NAS EMPRESAS ESTATAIS
}

\author{
ADILSON ABREU DALLARI*
}

I - Resumo da questão jurídica em exame. II - Evolução dos textos normativos. III - Discussão doutrinária. IV - Consideraçōes metodológicas. $V-$ Conclusões.

\section{I- Resumo da questão jurídica em exame}

A questão em debate neste estudo é relativamente simples: Estão ou não as empresas estatais obrigadas a observar as normas de licitações e contratos da Lei $n^{\circ}$ 8.666/93? Ou, dizendo de outro modo: Podem ou não as empresas estatais, em suas licitações, pautar-se por normas próprias, específicas para cada empresa, estabelecendo procedimentos simplificados? Explica-se: a resposta a tais indagações é simples; mas de difícil demonstração, obrigando que se proceda a uma ampla e aprofundada verificação do cenário, ou seja, do sistema jurídico no qual o problema está inserido.

Após a promulgação da Constituição Federal de 1988 as empresas estatais, independentemente de serem prestadoras de serviços públicos ou exploradoras de atividades econômicas, vinham realizando suas licitações com observância das normas gerais estabelecidas pela legislação federal, muito especialmente da Lei ${ }^{\circ} 8.666$, de 21.06.93, sem qualquer problema, por força do disposto no art. 37 , inciso XXI, da Carta Magna.

Entretanto, com o advento da Emenda Constitucional $n^{\circ} 19$, de 04.06.98, essa observância uniforme passou a ser questionada, diante do tratamento diferenciado dado pelo texto constitucional às empresas estatais, especialmente aquelas destinadas à exploração de atividades econômicas, em face da nova redação do art. 173 da Constituição Federal.

$\mathrm{Na}$ verdade, o problema jurídico em exame surgiu um pouco mais cedo, com a edição da Emenda Constitucional $n^{\circ} 9$, de 09.11.95, que alterou parcialmente $o$ art.

* Professor Titular de Direito Administrativo da PUC/SP.

R. Dir. Adm.,

Rio de Janeiro, 229: 69-85, Jul./Set. 2002 
177 da Constituição Federal, restringindo o monopólio estatal do petróleo. A nova disciplina constitucional dessa matéria deu ensejo à edição da Lei $\mathrm{n}^{\circ} 9.478$, de 06.08.97, em cujo art. 67 já ficava estabelecido que a PETROBRAS (empresa estatal exploradora de atividade econômica) deveria realizar suas licitações com base em “procedimento licitatório simplificado", aprovado pelo Presidente da República.

Entende parte considerável da doutrina que, enquanto não for editado o estatuto das empresas estatais exploradoras de atividade econômica, previsto no art. 173, § $1^{\circ}$, da Constituição Federal, as empresas estatais exploradoras de atividades econômicas devem observar fielmente as normas da Lei $n^{\circ} 8.666 / 93$.

\section{II - Evolução dos textos normativos}

Como ponto de partida do presente estudo, convém deixar bem claro que as empresas estatais integram a chamada administração indireta e, nessa condição, continuam sendo abrangidas pelo disposto no Art. 37 "caput" e inciso XXI, da Constituição Federal, inciso este que permanece, até hoje, com sua redação original:

"Art. 37. A administração pública direta e indireta de qualquer dos Poderes da União, dos Estados, do Distrito Federal e dos Municípios obedecerá aos princípios de legalidade, impessoalidade, moralidade, publicidade e eficiência e, também, ao seguinte:

XXI - ressalvados os casos especificados na legislação, as obras, serviços, compras e alienações serão contratados mediante processo de licitação pública que assegure igualdade de condições a todos os concorrentes, com cláusulas que estabeleçam obrigaçōes de pagamento, mantidas as condiçóes efetivas da proposta, nos termos da lei, o qual somente permitirá as exigências de qualificação técnica e econômica indispensáveis à garantia do cumprimento das obrigações".

Mesmo as empresas estatais exploradoras de atividades econômicas, salvo quando no exercício de suas respectivas atividades negociais específicas, na prática de atos rotineiros de comércio e indústria para os quais foram criadas (incompatíveis com a licitação), estão, em princípio, obrigadas a licitar, não obstante tenham personalidade jurídica de direito privado. Não é o caso de se repetir neste estudo uma antiga e já superada controvérsia.

Todavia, merecem especial cuidado os dispositivos constitucionais que tiveram suas respectivas redações alteradas ao longo do processo de modernização e reforma do aparelho do Estado, que teve seu ponto alto no momento da promulgação da Emenda Constitucional $\mathrm{n}^{\circ} 19$, de 04.06.98.

Primeiramente, cabe transcrever em sua redação original, o inciso XXVII, do art. 22 da CF, que, ao tratar das competências da União, dispunha que competia a ela estabelecer: 
“XXVII - normas gerais de licitação e contratação, em todas as modalidades, para a administração pública, direta e indireta, incluídas as fundações instituidas e mantidas pelo Poder Público, nas diversas esferas de governo, e empresas sob seu controle;" (redação original)

Tal dispositivo não fazia qualquer distinção entre entidades da administração indireta: todas elas, todas as empresas estatais, estavam sujeitas à observância das mesmas normas.

Essa situação jurídica, entretanto, foi alterada com o advento da $E C \mathrm{n}^{\circ} 19 / 98$, que deu ao mesmo dispositivo a seguinte redação:

"XXVII - normas gerais de licitação e contratação, em todas as modalidades, para as administrações públicas diretas, autárquicas e fundacionais da Uniāo, Estados, Distrito Federal e Municípios, obedecido o disposto no art. 37, XXI, e para as empresas públicas e sociedades de economia mista, nos termos do art. $173, \S 1^{\circ}$, III;". (redação dada pela EC $\left.n^{\circ} 19\right)$

Observe-se que este inciso menciona "empresas públicas e sociedades de economia mista", mas faz remissão ao art. 173, que cuida apenas e tão-somente daquelas que se dedicam à exploração de atividades econômicas.

A nova redação faz efetivamente uma indiscutível distinção no tocante apenas às empresas estatais exploradoras de atividades econômicas. Cabe, aqui e agora, apenas lembrar o vetusto aforismo: onde a lei não distingue, o intérprete não pode distinguir. Portanto, as empresas estatais prestadoras de serviços públicos continuam devendo fiel observância às normas gerais de licitações estabelecidas pela legislação federal (Lei $n^{\circ}$ 8.666/93). Mas vale lembrar que, em contrapartida: onde a lei distingue o intérprete não pode deixar de distinguir.

Esta mesma linha de pensamento deve ser aplicada ao art. $173 \mathrm{da} C F$, que disciplina a exploração de atividade econômica pelo Estado, com relação à parte aqui transcrita:

"Art. 173. Ressalvados os casos previstos nesta Constituição, a exploração direta de atividade econômica pelo Estado só será permitida quando necessária aos imperativos da segurança nacional ou a relevante interesse coletivo, conforme definidos em lei."

$\$ l^{\circ}-$ A empresa pública, a sociedade de economia mista e outras entidades que explorem atividade econômica sujeitam-se ao regime jurídico próprio das empresas privadas, inclusive quanto às obrigações trabalhistas e tributárias." (redação original)

Nessa redação original, em consonância com a redação original do art. 22, nem se mencionava a questão das licitações, mas, agora, em face da remissão feita pelo art. 22, estabelecendo uma distinção, foi estabelecido, no tocante às licitações, um 
novo regime, diferenciado, para as empresas estatais exploradoras de atividade econômica:

"Art.173. Ressalvados os casos previstos nesta Constituição, a exploração direta de atividade éconômica pelo Estado só será permitida quando necessária aos imperativos da segurança nacional ou a relevante interesse coletivo, conforme definidos em lei.

$\S I^{\circ}$ A lei estabelecerá o estatuto jurílico da empresa pública, da sociedade de economia mista e de suas subsidiárias que explorem atividade econômica de produção ou comercialização de bens ou de prestação de serviços, dispondo sobre:

I - sua função social e formas de fiscalização pelo Estado e pela sociedade;

II - a sujeição ao regime jurídico próprio das empresas privadas, inclusive quanto aos direitos e obrigações civis, comerciais, trabalhistas e tributários;

III - licitação e contratação de obras, serviços, compras e alienações, observados os princípios da administração pública;

IV - a constituição e o funcionamento dos conselhos de administração e fiscal, com a participação de acionistas minoritários;

$V$ - os mandatos, a avaliação de desempenho e a responsabilidade dos administradores." (redação dada pela EC $\mathrm{n}^{\circ} 19$ ).

Está perfeitamente claro, no $\S 1^{\circ}$, que "o estatuto jurídico da empresa pública, da sociedade de economia mista e de suas subsidiárias que explorem atividade econômica de produção ou comercialização de bens ou de prestação de serviços" será estabelecido por uma futura lei; mas também está igualmente claro, no inciso III, que essas entidades estão obrigadas a realizar suas licitações e contratações de obras, serviços, compras e alienações, com observância dos "princípios da administração pública" e não mais das mesmas normas aplicáveis à administração direta e outras entidades da administração indireta.

Entendem alguns, entretanto, com base em outra linha de pensamento e num processo interpretativo radicalmente diferente do esposado neste estudo, que essa desoneração somente se verificaria após a edição do estatuto de tais empresas. Tal entendimento somente se sustenta caso se atribua ao dispositivo constitucional em exame (o $\$ 1^{\circ}$ do art. 173 e seus incisos) a qualidade de um NADA JURÍDICO, de uma norma total e absolutamente ineficaz.

Tal entendimento contraria flagrantemente princípios fundamentais de hermenêutica constitucional e outros postulados da ciência que estuda a interpretação das normas jurídicas, que passam a ser examinados, tomando-se como ponto de partida o fato de que tanto a $E C n^{\circ} 9$, quanto a $E C n^{\circ} 19$, integram um processo de reforma do Estado, com vetores, valores e objetivos perfeitamente definidos.

Conforme ensina Antonino Pensovecchio Li Bassi, em sua preciosa obra sobre “L' Interpretazione delle Nome Costituzionale" (Milano, 1972, p. 62 e 81). numa tradução para o português: 
"O intérprete não deve esquecer que a Constituição contempla as opções políticas fundamentais de um dado sistema jurídico, devendo o intérprete das disposições constitucionais atentar cuidadosamente para os valores políticos consagrados nos princípios fundamentais esposados pela Constituiçāo".

"O intérprete das normas constitucionais deve aplicar no seu trabalho também o critério evolutivo, atentando para com a realidade e referindo as normas isoladas a um sistema constitucional em contínua evolução, como decorrência das mutações das exigências político-sociais da coletividade. Deve aplicar as normas não com base no sistema no qual o dispositivo historicamente nasceu, mas, sim, com base no sistema atual no qual vive."

"Deve levar em conta a realidade concreta, na qual operam as normas constitucionais, para trazer do exame da realidade oportunos elementos de valorização que permitam ajustamento ao processo evolutivo das normas e evitar conclusões incompativeis com a vida real".

Não se pode interpretar a Constituição de maneira avarenta, dando pouca ou nenhuma importância a seus dispositivos. Nesse trabalho, não é possível olhar para traz, a não ser para observar a linha de evolução dos dispositivos.

Convém, portanto, examinar o que a doutrina está atualmente dizendo a respeito do problema objeto deste estudo.

\section{III - Discussão doutrinária}

Primeiramente convém afastar qualquer identidade, no tocante às licitações, entre, de um lado, as empresas estatais exploradoras de atividade econômica em regime de competição e, de outro lado, as empresas privadas. Sem ir muito longe, é suficiente destacar este preciosíssimo ensinamento:

"Questão que, mesmo hoje, merece certa detença é a de se saber se sociedades de economia mista e empresas públicas exploradoras de atividade econômica estão ou não sujeitas ao dever de licitação. Estarão também elas obrigadas a licitar, tendo em vista que o art. $173, \S 1^{\circ}, I I$, da Constituição as declarou "sujeitas ao regime próprio das empresas privadas"? Parece-nos que, com as significativas ressalvas adiante feitas, a resposta terá de ser afirmativa. E que, pois, não se pode tomar ao pé da letra a dicção do preceptivo cogitado.

Com efeito, em inúmeros outros artigos da Constituição - como no art.37. XXI, atinente à licitação - encontram-se normas que impõe a quaisquer entidades da Administração indireta regramento diverso do aplicável às empresas privadas, sem discriminar se são ou não exploradoras de atividade econômica. E em nenhum deles caberia duvidar de que também estas últimas estão abrangidas pelos sobreditos preceitos, conquanto as normas em questão thes confiram tratamento distinto do que se aplica às 
empresas privadas. Assim, também, não há por que pretender que o art.37, $X X I$, esbarre no art.I73, § $1^{\circ}, I^{\prime \prime}$. (Celso Antônio Bandeira de Mello, "Curso de Direito Administrativo", $14^{\mathrm{a}}$ ed., Malheiros, São Paulo, 2002, p. 478)

Admitindo-se, portanto, que as empresas estatais exploradoras de atividades econômicas (salvo quanto ao exercício de suas atividades negociais específicas, ou seja, na prática de atos rotineiros de comércio e indústria, que são incompatíveis com a licitação) estão obrigadas a escolher seus contratantes mediante algum procedimento licitatório, resta saber como deverá ser tal procedimento.

Autores da maior autoridade e dignos do maior respeito entendem que a observância das normas da Lei $n^{\circ} 8.666 / 93$ é obrigatória, até que seja editado o previsto estatuto das empresas estatais exploradoras de atividades econômicas:

"Quanto à licitação e contratos, o artigo 37, XXI, da Constituição diz que, ressalvados casos especificados na legislação, as obras, serviços, compras e alienações serão contratadas mediante licitação.

A Emenda Constitucional n $19 / 98$ trouxe alguma alteração na matéria de licitação e contrato referente às empresas públicas e sociedades de economia mista. Isto porque, ao alterar a redação do artigo 22, XXVII, fez remissão, com relação a tais entidades, ao artigo $173, \S 1^{\circ}$, III; segundo esse dispositivo, a lei que definir o estatuto jurídico da empresa pública. da sociedade de economia mista e das suas subsidiárias que explorem atividade econômica de produção ou comercializaçño de bens ou de prestação de serviços disporá sobre "licitação e contratação de obras, serviços. compras e alienações, observados os princípios da administração pública".

Com essa alteração, abriu-se ensejo a que se estabeleça, normas sobre licitação e contratos diferentes para as empresas estatais. Enquanto não for estabelecido o estatuto jurídico previsto no artigo $173, \S 1^{\circ}$, continuam a aplicar-se as normas da Lei $n^{\circ} 8.666 / 93$, já que o dispositivo constitucional não é auto-aplicável". (Maria Sylvia Zanella di Pietro, "Direito Administrativo", Atlas, São Paulo, 14ª edição, 2002, p. 394)

Essa consagrada autora destaca a distinção feita pela Constituição; afirma que a legislação ordinária poderá dar um tratamento diferenciado para as empresas em questão, mas, considerando que o dispositivo constitucional não é auto-aplicável (entendimento esse do qual respeitosamente divergimos. pelos motivos e fundamentos adiante explicitados), diz que a Lei $n^{\circ} 8.666 / 93$ deverá continuar sendo observada. Implicitamente, diz que a aplicabilidade da distinção constitucionalmente já estabelecida somente se dará com a edição da lei prevista no $\S 1^{\circ}$ do art. 173 da CF.

Outros juristas de igual nomeada, esposam entendimento um pouco diferente. Marçal Justen Filho concorda em que a eficácia deve promanar da "legislação infraconstitucional", da legislação ordinária federal, mas não restringe a uma determinada e específica lei: 
"Respeitar os principios da administração pública pode significar tanto necessidade de observar todos eles (tal como se põe com a Administração direta) como também pode ser interpretado como respeitar apenas os mais essenciais.

Enfim, a questão se resolverá no âmbito da legislação infraconstitucional". (Marçal Justen Filho, "Comentários à Lei de Licitações e Contratos Administrativos", Dialética, São Paulo, $7^{a}$ edição, 2000, p. 23)

Cabe destacar, entretanto, que esse mesmo renomado mestre, na mesma obra, logo adiante, destaca a inconsistência e o despropósito da aplicação das normas da Lei $n^{\circ} 8.666 / 93$ às empresas estatais exploradoras de atividades econômicas, exatamente em face do papel que foi a elas reservada no novo cenário desenhado pelo processo de reforma e modernização do Estado:

"A disciplina das contratações administrativas deve ser compativel com o funcionamento eficiente das organizações administrativas. Logo, as entidades que desenvolvem atividade econômica não podem sujeitar-se ao mesmo regramento licitatório previsto para a Administração direta e autárquica. Isso é incompativel com os próprios fins buscados por elas e acarreta frustração de sua competitividade no mercado".

"É imperioso diferenciar o regime de licitaçōes entre as pessoas integrantes da Administração Pública. A sistemática padrão da Lei $n^{\circ} 8.666$ pode ser aplicada à Administração direta e autárquica. Também as entidades administrativas prestadoras de serviços públicos podem sujeitar-se ao mesmo regime. Mas as pessoas que desempenham atividade econômica têm de ser submetidas a regime distinto. Isso não significa liberá-las das regras sobre licitação e publicidade, mas adotar disciplina mais simples, dinâmica e compativel com a natureza da sua atuação. A sumariedade das formalidades no âmbito licitatório deverá ser compensada pelo incremento dos controles no âmbito de motivação e eficiência, com ampla responsabilização dos administradores por contrataçôes despropositadas". (Marçal Justen Filho, op. cit., p. 23 e 24)

Para que fiquem mais claros os valores, os objetivos do processo de modernização e reforma do aparelho do Estado, que tem como um dos principais princípios a implantação da chamada administração gerencial, convém ouvir o mais autorizado de seus comentadores, o então Ministro encarregado exatamente de conduzir e desenvolver tal processo:

"Algumas características básicas definem a administração pública gerencial. É orientada para o cidadão e para a obtenção de resultados; pressupõe que os políticos e os funcionários públicos são merecedores de grau limitado de confiança; como estratégia, serve-se da descentralização $e$ do incentivo à criatividade e à inovação; e utiliza o contrato de gestão como instrumento de controle dos gestores públicos. 
Enquanto a administração pública burocrática concentra-se no processo; em definir procedimentos para a contratação de pessoal, para a compra de bens e serviços; e em satisfazer as demandas dos cidadãos, a administração pública gerencial orienta-se para os resultados".

"Para que se proceda ao controle dos resultados, descentralizadamente, em uma administração pública, é preciso que políticos e funcionários públicos mereçam, pelo menos certo grau de confiança. Confiança limitada, permanentemente controlada por resultados, mas ainda assim suficiente para permitir a delegação, para que o gestor público possa ter liberdade de escolher os meios mais apropriados ao cumprimento das metas prefixadas". (Luiz Carlos Bresser Pereira, Gestāo do setor público: estratégia e estrutura para um novo Estado, in "Reforma do Estado e Administração Pública Gerencial", Editora Fundação Getúlio Vargas, Rio de Janeiro, $1^{a}$ edição, 1998, p. 28 e 30 )

Voltando ao campo dos estudos jurídicos, merece destaque uma preciosa síntese feita por um dos mais atilados observadores e comentadores da chamada reforma administrativa:

"Em suma, cria-se uma entidade ou órgão público para satisfazer interesses públicos (finalidade), atribuindo-se-lhe poderes em tese (competência) para que sejam exercidos da forma necessária (flexibilidade) para efetivamente atendê-los em concreto (eficiência)". (Diogo de Figueiredo Moreira Neto, "Mutações do Direito Administrativo", Renovar, Rio de Janeiro, 2000, p.29-30)

Tendo ficado perfeitamente definido que a tônica do controle administrativo migrou dos "processos" para os "resultados" (sem, é claro, dispensar totalmente o controle dos processos) como objetivo e consequiência das alterações constitucionais acima referidas, especialmente no tocante às empresas estatais exploradoras de atividades econômicas, é preciso, agora, enfrentar a questão da eficácia da norma contida no $\S 1^{\circ}$ e seus incisos, do art. 173 da Constituição Federal, consignando um tratamento diferenciado no tocante aos procedimentos licitatórios.

Para que se possa deixar clara a orientação adotada no tocante ao problema da eficácia das normas constitucionais, recorre-se, agora, ao magistério de um dos mais respeitados publicistas nacionais que já se debruçou sobre a questão da aplicabilidade das normas constitucionais, para afastar alguns mitos e construir pontos firmes de apoio:

"A classificação pura e simples das normas constitucionais em autoaplicáveis e não auto-aplicáveis não corresponde, com efeito, à realidade das coisas e às exigências da ciência jurídica, nem às necessidades práticas 
de aplicação das constituições, pois sugere a existência, nestas, de normas ineficazes e destituídas de imperatividade, como bem demonstra o conceito de Cooley, quando fala em regras "sem estabelecer normas por cujo meio se logre dar a esses principios vigor de lei". O próprio Ruy, no entanto, já reconhecia que "não há, numa Constituição, cláusulas, a que se deva atribuir meramente o valor moral de conselhos, avisos ou lições. Todas têm força imperativa de regras, ditadas pela soberania nacional ou popular aos seus órgãos". Nem as normas ditas auto-aplicáveis produzem por si mesmas todos os efeitos possiveis, pois são sempre passiveis de novos desenvolvimentos mediante legislação ordinária, nem as ditas não auto-aplicáveis são de eficácia nula, pois produzem efeitos jurídicos e têm eficácia, ainda que relativa e reduzida.

Cada norma constitucional é sempre executável por si mesma até onde possa, até onde seja suscetível de execução. O problema situa-se, justamente, na determinação desse limite, na verificação de quais os efeitos parciais e possiveis de cada uma". (José Afonso da Silva, "Aplicabilidade das Normas Constitucionais", Malheiros, São Paulo, $3^{a}$ edição, 1998, p. 75-76)

Deixando claro, desde já, que não existe dispositivo constitucional inócuo, deixando claro que toda norma constitucional sempre tem um mínimo de eficácia, salientando que o grau de eficácia ou de aplicabilidade pode variar, JOSÉ AFONSO DA SILVA classifica as normas constitucionais, quanto à eficácia, em normas de eficácia plena, de eficácia contida e normas de eficácia limitada, passando a explicitar cada uma dessas espécies:

"Na primeira categoria incluem-se todas as normas que, desde a entrada em vigor da constituição, produzem todos os seus efeitos essenciais (ou têm a possibilidade de produzi-los), todos os objetivos visados pelo legislador constituinte, porque este criou, desde logo, una normatividade para isso suficiente, incidindo direta e imediatamente sobre a matéria que lhes constitui objeto. O segundo grupo também se constitui de normas que incidem imediatamente e produzem (ou podem produzir) todos os efeitos queridos, mas prevêem meios ou conceitos que permitem manter sua eficácia contida em certos limites, dadas certas circunstâncias. Ao contrário, as normas do terceiro grupo são todas as que não produzem, com a simples entrada em vigor, todos os seus efeitos essenciais, porque o legislador constituinte, por qualquer motivo, não estabeleceu, sobre a matéria, uma normatividade para isso bastante, deixando essa tarefa ao legislador ordinário ou a outro órgão do Estado". (José Afonso da Silva, op. cit., p. 82-83)

Discorrendo, mais adiante, sobre esta última espécie, as normas de eficácia limitada, dentre as quais estão as chamadas normas programáticas, José Afonso da Silva dá ênfase a uma de suas características ou a um de seus efeitos imediatos: 
"A caracterização das normas programáticas como princípios gerais informadores do regime político e de sua ordem jurídica dá-lhes importância fundamental. como orientação axiológica para a compreensão do sistema juridico nacional. O significado disso consubstancia-se no reconhecimento de que têm elas uma eficácia interpretativa que ultrapassa, nesse ponto, a outras do sistema constitucional ou legal, porquanto apontam os fins sociais e as exigências do bem comum, que constituem vetores da aplicação da lei". (José Afonso da Silva, op. cit., p. 157)

É bastante consolidado na doutrina o entendimento no sentido de que toda norma constitucional é dotada de, pelo menos, um mínimo de eficácia, que nunca pode ser desconsiderado, conforme está sintética e objetivamente enfocado neste precioso excerto doutrinário:

"Não existem normas constitucionais destituídas de eficácia, embora nem todas tenham, por si mesmas, a normatividade suficiente para gerar seus efeitos essenciais, o que depende da completude da norma, da sua densidade normativa. Dessa forma, pode-se falar em normas constitucionais de alta densidade normativa, aptas a gerar, diretamente, e sem intervenção do Poder Público, principalmente, do Legislador, os seus efeitos essenciais, ao lado de normas com baixa densidade que podem, sem a interpositio legislatoris, gerar seus efeitos principais, visto que, em virtude de uma normatividade mínima que se encontra presente em toda e qualquer norma constitucional, sempre produzem algum efeito, apresentando um certo grau de eficácia". (Regina Maria Macedo Nery Ferrari, "Normas constitucionais programáticas", RT, 2001, p. 127.)

Somando-se estas últimas lições com aquelas acima traduzidas, de ANTONINO PENSOVECCHIO LI BASSI, chega-se a duas conclusões fundamentais: a) as normas constitucionais de eficácia limitada, as normas programáticas, as normas cuja eficácia plena depende da edição de outras normas, possuem, sim, um mínimo de eficácia, servindo, no mínimo, como um vetor interpretativo, condicionando a interpretação e aplicação da legislação ordinária: b) as normas da legislação ordinária que contrariarem normas constitucionais, ainda que de eficácia limitada ou programáticas, perdem eficácia, perdem seu fundamento de validade, são, em síntese, inconstitucionais.

Ou seja: mesmo que a eficácia plena fique na dependência do legislador ordinário, é absolutamente certo que o mínimo de eficácia, sempre existente, impede a edição de normas da legislação ordinária que contrariem a norma constitucional de eficácia limitada e, o que é mais importante, torna inconstitucionais disposições de lẹis ordinárias já existentes com ela incompatíveis. 


\section{IV - Considerações metodológicas}

A questão fundamental objeto do presente estudo (necessidade ou não de observância, pelas empresas estatais exploradoras de atividades econômicas, das normas da Lei $n^{\circ} 8.666 / 93$ ) está diretamente ligada a problemas de interpretação das normas jurídicas. A doutrina já evoluiu o suficiente para saber que, normalmente, a lei comporta uma pluralidade de interpretações. Partindo de diferentes pressupostos ou animado por diferentes valores, intérpretes distintos podem chegar a conclusões até conflitantes.

Por isso mesmo, para se obter uma interpretação a mais neutra e imparcial possível, é preciso valer-se de uma pluralidade de métodos interpretativos. Para se aferir a licitude ou ilicitude de determinada conduta, é preciso, também, considerar o conjunto normativo, as finalidades almejadas pela lei e o contexto fático onde ocorreu o problema em exame.

Não é possível determinar o conteúdo normativo de um dispositivo isolado. Toda e qualquer disposição normativa faz parte de um contexto. O conteúdo normativo de cada dispositivo tem limites, que fluem de outras normas, de princípios jurídicos afirmados pelo sistema jurídico ou até mesmo por princípios gerais e universais de direito. Toda norma jurídica é instrumental; visa a realização de uma específica finalidade que o sistema jurídico considera como de interesse público.

Interpretar os textos jurídicos, para aferir o real significado de seus mandamentos, não é um fim em si e nem uma atividade lúdica. O trabalho do intérprete é instrumental ou, pelo menos, deve estar voltado para a busca da solução mais adequada e mais justa dos problemas suscitados.

Sem ousar, o direito não evolui. Mas ousar não é agir irresponsavelmente; é, sim, procurar extrair do sistema jurídico o máximo de seu conteúdo, como fundamento para a concretização de seus princípios mais importantes, de maior hierarquia, que estão muito acima de meras normas isoladas.

A primeira e mais elementar lição para quem pretende interpretar textos normativos é dada por Carlos Maximiliano ("Hermenêutica e Aplicação do Direito", $9^{\mathrm{a}}$ ed. Edit. Forense, 1984, p. 166):

"Deve o Direito ser interpretado inteligentemente: não de modo que a ordem legal envolva um absurdo, prescreva inconveniências, vá ter a conclusões inconsistentes ou impossiveis. Também se prefere a exegese de que resulte eficiente a providência legal ou válido o ato, à que torne aquela sem efeito, inócua, ou este, juridicamente nulo".

É essencial que o jurista conheça o sistema jurídico como um todo, para que possa dar a cada norma isolada uma interpretação inteligente, compatível com o conjunto normativo do qual ela necessariamente faz parte. Um dispositivo isolado pode comportar uma pluralidade de interpretações: examinando-se esse dispositivo à luz do contexto a que pertence, em face do sistema jurídico, é possível extrair a melhor interpretação, a interpretação mais ajustada ao específico caso em exame. 
"Destarte, assumindo uma ótica ampliativa e mais bem equipada, a interpretação sistemática deve ser definida como uma operação que consiste em atribuir a melhor significação, dentre várias possiveis, aos princípios, às normas $e$ aos valores jurídicos, hierarquizando-os num todo aberto, fixando-lhes o alcance e superando antinomias, a partir da conformação teleológica, tendo em vista solucionar os casos concretos". (Juarez Freitas, "A Interpretação sistemática do Direito", Malheiros Editores, 1995, p. 54)

A menção feita à conformação teleológica indica a absoluta necessidade de se levar em consideração, na interpretação de um dispositivo, a finalidade por ele almejada. Algumas vezes essa finalidade está expressa no texto legal, outras vezes ela está implícitil nu pressuposta e somente pode ser vista mediante um exame mais amplo e mais aprotundado, inclusive diante de dados da realidade histórica dos fatos da vida.

"A norma geral pode ser entendida, é claro, pelo sentido abstrato das palavras por ela utilizadas. Trata-se, porém, de mero entendimento prévio. Esse entendimento não exaure o âmbito da incidência normativa, pois ele só se consuma perante os fatos concretos da vida". (Voto do Desembargador Federal Newton de Lucca no MS n ${ }^{\circ}$ 94.03.093099-3-SP - TRF $3^{\text {a }}$ Região, publicado no Boletim AASP - $\mathrm{n}^{\circ} 2043$ - p. 473)

Volta-se, portanto, a enfocar a questão da finalidade, do específico interesse público a ser perseguido pela prática de determinado ato ou pela celebração de determinado contrato. Esse enfoque instrumental do direito deu força ao crescimento de um método de interpretação e aplicação do direito denominado jurisprudência dos interesses.

"A jurisprudência de interesses surgiu em reação à jurisprudência de conceitos que dominava o pensamento jurídico alemão (e francês) no século passado, e afirmava ser a lei perfeita, dela tirando-se soluções corretas para as questões judiciais, através de operações lógicas apropriadas. Como escola de cunho sociológico, a jurisprudência de interesses entende o direito em intima correlação com a realidade social, sem afastar-se, contudo, do primado da lei como fonte do direito; dela extrair-se-iam as soluções, não por deduções lógicas, mas verificando-se os interesses que ela teve em inira proteger". (Maria da Conceição Ferreira Magalhães, "A Hermenêutica Jurídica", Editora Forense, 1989, p. 73.)

Quando se cuida de interpretar preceitos de direito administrativo, o norte há de ser sempre a satisfação do interesse público. Advirta-se, entretanto, que não compete ao intérprete ou aplicador da lei escolher, criar ou inventar um interesse público. O interesse público a ser satisfeito deve emergir do sistema jurídico, especialmente de seus princípios fundamentais, afirmados primeiramente na Constitui- 
ção, cuja invocação ou utilização depende das circunstâncias de ordem fática, que determinarão qual a solução mais razoável entre as que seriam teórica ou abstratamente possiveis.

A interpretação concreta, portanto, não se resume a uma dedução de lógica pura, destinada a desvendar a única solução correta e verdadeira, mas, sim, conforme explica com invejável clareza Christiano José de Andrade ("O problema dos métodos da interpretação jurídica", RT, 1992, p. 80 e 82) deve buscar a identificação do comportamento mais razoável:

"A lógica do razoável, aplicada à interpretação jurídica, supera aquela pluralidade de métodos. Diante de qualquer caso, fácil ou difícil, há que se proceder razoavelmente. A ciência jurídica não tem condições de eleger um método interpretativo, como o único correto. Mas em cada caso, o juiz deve interpretar a lei, segundo o método que conduz à solução mais justa entre todas possiveis, inclusive quando impertinentemente o legislador tenha ordenado um determinado método de interpretação. De sorte que o método correto é o que em determinado caso nos conduziu à solução que consideramos satisfatória. E este método é o da lógica do razoável ou do humano"

Afaste-se, de imediato, qualquer alegação de incompatibilidade entre os princípios da legalidade e da razoabilidade, em matéria de direito público, especialmente administrativo. O princípio da legalidade determina a submissão à lei, mas, conforme já foi salientado, é usual que a norma legal admita uma pluralidade de interpretações. Cabe ao intérprete e aplicador da lei optar pela interpretação mais razoável, em função das circunstâncias do caso concreto e das finalidades almejadas.

Atualmente, além de acatar o princípio da legalidade, é preciso dar atendimento também a um outro novo e significativo princípio constitucional da administração pública, o princípio da eficiência, introduzido no cenário jurídico nacional pela Emenda Constitucional $n^{\circ} 19 / 98$, a chamada emenda da reforma administrativa, sobre o qual, em obra escrita em parceria com Sérgio Ferraz, já fizemos algumas ponderações:

"A Emenda Constitucional 19, de 04.06.98, conhecida como "Emenda da Reforma Administrativa", trouxe profundas modificações na Administração Pública brasileira. O propósito fundamental dessa reforma era a substituição do antigo modelo burocrático, caracterizado pelo controle rigoroso dos procedimentos, pelo novo modelo gerencial, no qual são abrandados os controles de procedimentos e incrementados os controles de resultados. Essa linha de pensamento, esse novo valor afirmado pela Constituição, não pode ser ignorado pelo intérprete e aplicador da lei.

Não por acaso, aos princípios já previstos na redação original do art. 37, foi acrescentado o princípio da eficiência. É obvio que esse princípio já estava implícito. Ao torná-lo explícito, ao afirmá-lo expressamente, o que 
se pretendeu foi demonstrar a redobrada importância que ele passou a ter. Em termos práticos, deve-se considerar que, quando mera formalidade burocrática for um empecilho à realização do interesse público, o formalismo deve ceder diante da eficiência.

Isso significa que é preciso superar concepções puramente burocráticas ou meramente formalisticas, dando-se maior ênfase ao exame da legitimidade, da economicidade e da razoabilidade, em benefício da eficiência. Não basta ao administrador ciemonstrar que agiu bem, em estrita conformidade com a lei; sem se divorciar da legalidade (que não se confunde com a estrita legalidade), cabe a ele evidenciar que caminhou no sentido da obtenção dos melhores resultados". (Sérgio Ferraz e Adilson Abreu Dallari, "Processo Administrativo", Malheiros Editores, 2.000, p. 77 e 78.)

Não basta atuar de maneira conforme a lei. Não faz sentido emperrar a administração para dar estrito cumprimento à literalidade da lei. Agora é preciso mais: a administração deve buscar a forma mais eficiente de cumprir a lei, deve buscar, entre as soluções teoricamente possíveis, aquela que, diante das circunstânicias do caso concreto, permita atingir os resultados necessários à satisfação do interesse público.

Diante de uma dúvida a respeito de qual das possíveis interpretações deve ser aplicada, essa verificação sobe para um patamar mais alto. Tendo em vista os objetivos do presente estudo, cabe examinar, no tocante às empresas estatais exploradoras de atividades econômicas, qual delas melhor se ajusta aos princípios constitucionais vigentes, considerando os fatos que levaram a uma alteração dos dispositivos constitucionais pertinentes.

Essa necessidade de recorrer em níveis mais elevados, especialmente ao nível dos princípios constitucionais, é mais evidente quando se está diante de um aparente conflito entre duas leis.

No início deste estudo, ao se apresentar a questão jurídica a ser examinada, foi mencionado o caso específico da PETROBRÁS. Como se recorda, a Emenda Constitucional $n^{\circ} 9$, de 09.11.95, deu ensejo à edição da Lei $n^{\circ} 9.478$, de 06.08.97, em cujo art. 67 já ficava estabelecido que a PETROBRÁS (empresa estatal exploradora de atividade econômica) deveria realizar suas licitações com base em "procedimento licitatório simplificado", aprovado pelo Presidente da República. Aparentemente, haveria aí um conflito com a Lei $n^{\circ} 8.666$, de 21.06.93, que estabelece as normas gerais de licitações, de maneira obrigatória para a administração direta e indireta da União, dos Estados e dos Municípios.

Existe, entretanto, no cotejo dessas duas leis federais um importantíssimo elemento, uma distinção fundamental, que costuma passar despercebida; A Lei $n^{\circ}$ 8.666/93 é uma lei nacional, enquanto a Lei $n^{\circ}$ 9.478/97 é uma simples lei federal.

A caracterização e o significado dessa distinção somente podem ser feitos com auxíio do magistério do insuperável Geraldo Ataliba ("Estudos e Pareceres de Diretto Tributário", RT, 1980, vol. 3, p. 16): 
"Com efeito, ao Congresso Nacional incumbe editar leis nacionais e leis federais, cumulativamente. Embora sejam estas essencialmente distintas e inconfundíveis, dotadas que são de naturezas juridicas diversas - o que as coloca em campos diferentes - dificil parece, muita vez, discerni-las, principalmente em razão da circunstância de formalmente se assemelharem $e$, sobretudo, originarem-se, por processos semelhantes, do mesmo órgão

Há leis federais (ou da União), estaduais (ou dos Estados) e municipais (ou dos Municípios) dirigidas às pessoas na qualidade de administrados da União, dos Estados e dos Municípios e emendas dos legislativos, dessas entidades politicas, respectivamente. E há leis nacionais, leis brasileiras, voltadas para todos os brasileiros, indistintamente, abstração feita da circunstância de serem eles súditos desta ou daquela pessoa política. É que o Estado Federal brasileiro é pessoa de direito público internacional, categoria esta que nenhuma relação guarda com as eventuais divisões políticas internas. É o Brasil - Estado Brasileiro - pessoa soberana que figura, ao lado dos demais estados do mundo, no palco do direito das gentes. $E^{\prime}$ a perspectiva "exterior" ou de "efeitos exteriores" da personalidade jurídica do Brasil (Estado brasileiro)."

"Deve-se, nela, entretanto, distinguir a feição ou o aspecto nacional do aspecto federal - em oposição a federado. Seus órgãos são alternativa ou cumulativamente nacionais (vale dizer, brasileiro) e federais (vale dizer, da União), pessoa que se não confunde com estado federado algum. Seus instrumentos, entre os quais a lei, não são, concomitantemente, nacionais e federais. São-no exclusivamente uma ou outra coisa.

A grande dificuldade, pois, demora-se exatamente aqui: o órgão é o mesmo - no que interessa ao nosso tema, o Congresso - e o fruto de sua ação formalmente idêntico, embora substancialmente tão diverso: lei federal e lei nacional. Leis que o Congresso edita enquanto órgão do Brasil Estado Federal - leis da União, perspectiva de direito intemo do Estado Federal."

Diante dessas magníficas lições pode-se, agora, perceber algo perfeitamente claro e extremamente relevante: a Lei ${ }^{\circ} 8.666 / 93$. que estabelece normas gerais de licitações e contratos, é uma lei NACIONAL, e por essa razão, aplicável à União, aos Estados e aos Municípios; a Lei $n^{\circ}$ 9.478/97 é uma lei federal, aplicável apenas ao aparelho administrativo da União. A primeira foi editada com base na competência prevista no art. 22, XXVII, da Constituição Federal; a segunda foi editada com base na autonomia administrativa de todas as pessoas jurídicas de capacidade política que formam a Federação brasileira.

Após a promulgação da $\mathrm{EC} \mathrm{n}^{\circ} 9 / 95$, que alterou a configuração constitucional do monopólio então detido pela União, esta foi compelida a alterar a legislação ordinária decorrente e redefinir a configuração e as atribuições da PETROBRAS. Ao fazê-lo, já em meio ao processo de modernização e reforma administrativa, no tocante às licitações, no art. 67 da Lei do Petróleo, autorizou a simplificação dos 
procedimentos e conferiu ao Presidente da República a competência para aprovar, por decreto, um regulamento específico.

A Lei $n^{\circ} 9.478 / 97$ apenas permitiu um tratamento diferenciado à PETROBRAS e conferiu ao Presidente da República a competência para aprovar um único ato administrativo de caráter normativo aplicável apenas a uma única empresa estatal. Isso em nada afeta a Lei $n^{\circ} 8.666 / 93$, que não foi revogada, mesmo que parcialmente, pela Lei do Petróleo, embora esta tenha sido promulgada posteriormente.

Se alguma dúvida quanto à constitucionalidade do art. 67 da Lei $n^{\circ}$ 9.478/97 pudesse ter surgido quando de sua edição, essa eventual dúvida foi totalmente eliminada pela promulgação da Emenda Constitucional $n^{\circ} 19 / 98$, que, conforme já foi visto, expressamente autorizou um tratamento diferenciado para as empresas estatais exploradoras de atividade econômica. Não há dúvida alguma de que, hoje, esse artigo tem pleno e indiscutível suporte constitucional de validade.

A lei federal $n^{\circ} 9.478 / 97$ não briga com a lei nacional sobre a matéria. A Lei $\mathrm{n}^{\circ} 8.666 / 93$ continua em vigor e deve ser aplicada pela administração direta e indireta, salvo quando, como no caso da PETROBRAS, houver uma legislação específica, autorizando um tratamento diferenciado.

Registre-se, também, que a própria Lei n 8.666/93, em seu art. 119 já autorizava que entidades da administração indireta tivessem seus regulamentos próprios:

“Art.119. As sociedades de economia mista, empresas e fundaçōes públicas e demais entidades controladas direta ou indiretamente pela União e pelas entidades referidas no artigo anterior editarão regulamentos próprios devidamente publicados, ficando sujeitas às disposiçōes desta Lei.

Parágrafo único. Os regulamentos a que se refere este artigo, no âmbito da Administração Pública, após aprovados pela autoridade de nivel superior a que estiverem vinculados os respectivos órgãos, sociedades e entidades, deverão ser publicados na imprensa oficial."

A única observação a ser feita diz respeito à parte final do "capui" desse artigo, que diz: "ficando sujeitas às disposiçôes desta Lei". Essa parte não mais pode ser aplicada às empresas estatais que explorem atividades econômicas, pois isso se chocaria com o mínimo de eficácia do disposto no $\$ 1^{\circ}$, do art. 173 , da Constituição Federal.

Obviamente, não tem suporte constitucional o dispositivo legal que determina um comportamento uniforme, quando o texto constitucional superveniente estabelece um comportamento diferenciado. Se ainda remanescer alguma dúvida interpretativa, a melhor interpretação certamente será aquela mais ajustada aos valores e objetivos afirmados pelas novas normas constitucionais, que foram promulgadas exatamente para atender às necessidades atuais da coletividade.

Quando vier a ser editada a LEI NACIONAL, estabelecendo normas gerais, configuradoras do estatuto das empresas estatais exploradoras de atividades econômicas, caberá, então, verificar se os regulamentos eventualmente existentes, editados com base em leis federais específicas, estão ou não conformes com tais normas gerais. 
Mas é fora de dúvida que a falta desse estatuto não impede que a legislação ordinária específica estabeleça um regramento diferenciado, simplificado, para as licitações levadas a efeito pelas empresas estatais exploradoras de atividades econômicas, desde que sejam observados os princípios da administração pública.

Esta expressão "observados os princípios da administração pública" não significa que basta atender aos princípios expressamente referidos no art. 37, "caput" da Constituição Federal. Na verdade, devem ser observados todos os princípios da administração pública, tanto aqueles do art. 37 quanto outros contidos em outros dispositivos constitucionais e, ainda, os princípios doutrinários da administração pública.

Regulamento simplificado de licitação não se confunde com simulacro de licitação. Deverão ser observados também os princípios da licitação contidos na Lei $\mathrm{n}^{\circ}$ 8.666/93 (e não todos os seus dispositivos). O que se pode (e se deve) fazer é simplificar os procedimentos existentes, dispensando um sem número de particularidades e detalhes que servem somente para complicar a licitação e fomentar litígios perfeitamente evitáveis.

\section{$V$ - Conclusões}

Toda norma constitucional é dotada de um mínimo de eficácia. Mesmo as chamadas normas constitucionais programáticas impedem a produção de normas legais com elas conflitantes e retiram o fundamento de validade de normas legais conflitantes anteriormente editadas. No mínimo dos mínimos, a norma programática deve servir como um vetor interpretativo, condicionando a identificação da melhor interpretação dentre as possíveis.

As empresas estatais exploradoras de atividades econômicas, em suas licitações, podem valer-se dos procedimentos licitatórios simplificados estabelecidos ou autorizados por leis ordinárias, em face do disposto no art. $173, \S 1^{\circ}$, III, da Constituição Federal. Não pode ser inconstitucional o que está perfeitamente ajustado às normas, princípios, valores e objetivos da Constituição Federal, em sua redação atual.

As empresas estatais exploradoras de atividades econômicas que não estejam expressamente autorizadas, por lei, a se valer de regulamentos simplificados específicos e todas empresas estatais prestadoras de serviços públicos estão obrigadas a observar as normas da Lei $n^{\circ} 8.666 / 93$.

$\mathrm{O}$ art. 173 da $\mathrm{CF}$, em sua redação atual, já autoriza o legislador ordinário a estabelecer procedimentos simplificados para as empresas estatais exploradoras de atividades econômicas. 


\title{
Locação Residencial
}

\author{
Arthur Narciso de Oliveira Neto
}

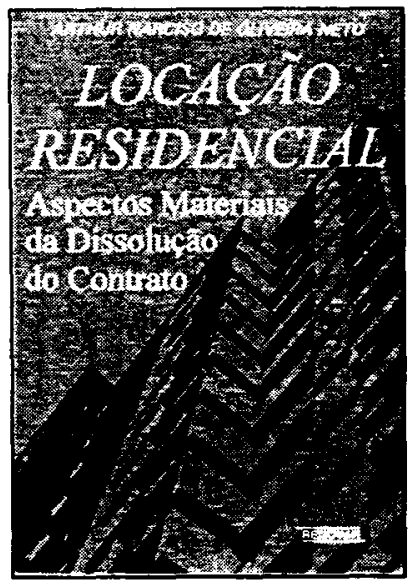

Este livro se propõe a fornecer uma visào geral do tema da dissolução do contrato de locação residencial a partir da disciplina estabelecida pela Lei $\mathrm{n}^{\mathrm{o}}$ 8.245, de 18.10.91, abordando as questōes de direito material emergentes de sua interpretação. São analisados os diversos dispositivos legais que, no âmbito da Lei $\mathrm{n}^{\circ}$ 8.245 regulamentam as hipóteses de dissolução do pacto locatício residencial. Para tais questões são apresentadas as soluçōes encontradas pelos doutrinadores que se dedicaram ao estudo do tema.

Ref. 0104

Form. 14x21

Brochura

268 págs. 1996

\section{Manual de Direito Administrativo}

\section{Odilia Ferreira da Luz Oliveira}

Obra escrita com objetivos puramente didáticos, é também de grande utilidade para o profissional de Direito, pois trata dos temas mais relevantes da disciplina, sob o enfoque do direito positivo, da doutrina nacional e estrangeira e da jurisprudência.

Ref. 0144

Brochura

Form. 14x21

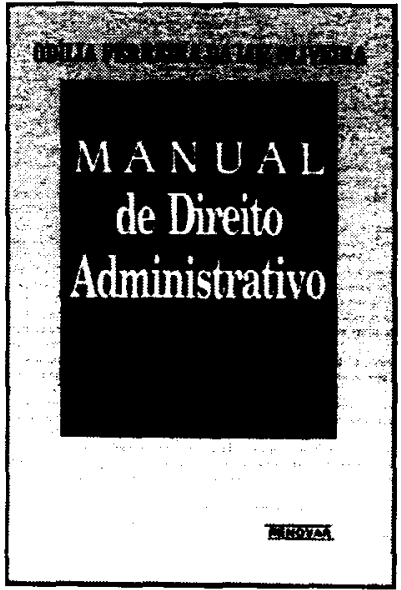

